\title{
Breaking BAT: can browning create a better white?
}

\author{
Amy Warner ${ }^{1}$ and Jens Mittag ${ }^{2}$ \\ ${ }^{1}$ AstraZeneca, CVMD IMED, Pepparedsleden 1, 43183 Mölndal, Sweden \\ ${ }^{2}$ Center of Brain, Behavior and Metabolism (CBBM), Medizinische Klinik 1, Universität zu Lübeck, \\ Ratzeburger Allee 160, 23562 Lübeck, Germany
}

Correspondence

should be addressed

to J Mittag

Email

jens.mittag@uni-luebeck.de

\begin{abstract}
Obesity and its comorbidities are a growing problem worldwide. In consequence, several new strategies have been proposed to promote weight loss and improve insulin sensitivity. Recently, it has been demonstrated that certain populations of white adipocytes can be 'browned', i.e., recruited to a more brown-like adipocyte, capable of thermogenesis through increased expression of uncoupling protein 1. The list of browning agents that induce these so-called beige adipocytes is growing constantly. However, the underlying mechanisms are often poorly understood, with the possibility that some of these agents cause browning as a secondary effect. Moreover, it remains unclear whether beige adipocytes can contribute sufficiently to affect whole-body energy expenditure in a functionally significant manner. This review presents an overview of the different molecular pathways leading to the induction of beige fat, including direct stimulation and indirect actions on the CNS or the immune system. We discuss the available evidence on the capacity of beige adipocytes to influence whole-body energy expenditure in rodents, and lastly outline the potential problems of translating browning capacity into the potential treatment of human metabolic diseases.
\end{abstract}

\author{
Key Words \\ - beige fat \\ - brown fat \\ - thermogenesis \\ - adipose tissue \\ - adipocytes \\ - UCP1 \\ - human \\ - mouse \\ - energy expenditure
}

\section{Introduction}

Obesity and its comorbidities are a growing worldwide health problem (Lobstein et al. 2015). Consequently, a lot of money and effort have been invested into understanding the problem, namely the overflow of lipid storage capacity in fat and inappropriate lipid deposition in other organs, as well as finding a potential therapeutic target to remove the excess fat. Recent studies have put forward preliminary evidence that the solution to the problem might lie in the fat itself, which could be turned to burning fuel instead of storing. This review summarizes the current knowledge on thermogenic adipose tissue and discusses its possible use in elevating energy expenditure to counteract obesity and metabolic diseases such as type 2 diabetes.

\section{Three kinds of fat}

To date, three major types of adipose tissue have been identified. White adipose tissue (WAT) is characterized by large white adipocytes with few mitochondria, and can be found in mice predominantly around the gonads (gonadal WAT, in male mice also called epididymal WAT) and subcutaneously close to the hind limbs (inguinal WAT) (Bartelt \& Heeren 2014). In humans, the major sites of WAT are under the skin (subcutaneous WAT) and associated with the digestive tract (visceral WAT), but it can also be found around internal organs such as the heart (epicardial WAT), kidney (perirenal WAT), lung (pulmonary WAT), and arteries (periadventitial WAT). WAT is generally considered as insulation against cold and as a safe storage space for fatty acids esterified into

Published by Bioscientifica Ltd 
triglycerides. When its storage capacity is exceeded, fatty acids can no longer be safely cleared from the systemic circulation and accumulate in other organs such as the liver and the muscle. This concept called lipotoxicity can subsequently lead to insulin resistance and result in type 2 diabetes and/or cardiovascular disease (Huang-Doran et al. 2010, Speakman \& O’Rahilly 2012).

Brown adipose tissue (BAT) is characterized by smaller lipid droplets and a high number of mitochondria. In rodents, BAT can be found in the interscapular region, located between the shoulders, and to a lesser extent as perirenal and axillary BAT (Sidossis \& Kajimura 2015). In humans, BAT is found in the neck region of infants with a volume of around $3.5 \mathrm{ml}$ (van Marken Lichtenbelt et al. 2009, Virtanen et al. 2009, Devlin 2015) - presumably to warm the blood supply of the brain (Sidossis \& Kajimura 2015, Symonds et al. 2015), supraclavicular area and perirenal area. Interestingly, although BAT and WAT both have the capacity to store lipids, they are derived from different progenitors. BAT is derived from precursor cells, which share the same lineage as skeletal muscle cells and are positive for Myf5. In contrast to skeletal muscle cells, BAT progenitors initiate the expression of PRDM16 and BMP7 during development, which drives them to become mature brown adipocytes (Seale et al. 2008, Tseng et al. 2008, Rajakumari et al. 2013).

The most important feature of brown fat is the capability to oxidize substrates to produce heat for facultative thermogenesis, which is required to maintain body temperature under conditions below thermoneutrality, and for arousal from torpor (Cannon \& Nedergaard 2004). At the molecular level this process depends on uncoupling protein 1 (UCP1), which shortcuts the proton gradient in mitochondria to produce heat instead of ATP. Several other molecules have been identified to be integral in BAT thermogenesis, the most important being cell death-inducing DFFA-like effector A, peroxisome proliferator-activated receptor gamma coactivator 1 , and receptor-interacting protein 140 (Uldry et al. 2006, Emont et al. 2015).

Recently, a third type of adipocyte was identified in rodents and termed beige or brite fat (brown in white; $\mathrm{Wu}$ et al. 2012). It is characterized by the expression of UCP1, but localized in classical WAT depots. Although beige adipocytes share some features of brown adipocytes such as similar levels of UCP1 in the mitochondria (Shabalina et al. 2013), their expression profile is distinctly different and even varies substantially depending on fat depot and origin. The lineage of these beige fat cells is not well understood. Evidence suggests that these cells can either arise directly from Myh11 + smooth muscle precursor cells (Long et al. 2014), from preadipocytes derived of mesodermal stem cells or through transdifferentiation from white adipocytes by a process called 'browning' (Asano et al. 2014, Carey et al. 2014, Sanchez-Gurmaches \& Guertin 2014, Sidossis \& Kajimura 2015, Symonds et al. 2015), although the term appears to be interchangeable in the literature regardless of origin.

The relative contributions of these pathways most likely depend on the specific depot of WAT hosting the UCP1-positive adipocytes, while perigonadal WAT does not readily produce beige adipocytes and also lacks a response to norepinephrine in terms of oxygen consumption, inguinal WAT shows significant browning (OkamatsuOgura et al. 2013). In humans, browning has also been observed (Wu et al. 2012, Jespersen et al. 2013), for instance in WAT associated with organs such as the epicardial depot (Sacks et al. 2013). To date, a plethora of browning agents has been identified (Fig. 1), and the list is likely to expand further. Therefore, it seems conceivable that several distinct pathways to beige adipocyte generation exist, and that they might be species- and WAT depot-specific.

\section{Ways of browning}

Browning of WAT can be achieved by several different means, including CNS activation modulating sympathetic output to WAT, the recruitment and activation of immune cells in WAT, or by direct action on white adipocytes or beige precursor cells (Fig. 1).

With regard to the CNS, the focus has been on neurons in the hypothalamus, which constitutes the master regulator of the autonomic nervous system. This includes pro-opiomelanocortin and agouti-related peptide producing neurons, well known for appetite regulation, which promote or inhibit browning respectively (Ruan et al. 2014, Dodd et al. 2015). Furthermore, hypothalamic GLP1 was found to stimulate browning (Beiroa et al. 2014, Lopez et al. 2015) and to increase triglyceride-derived fatty acid uptake in subcutaneous WAT (Kooijman et al. 2015). Likewise, 5-hydroxytryptamine neurons are also important to maintain beige UCP1 mRNA levels (McGlashon et al. 2015). These examples, which are likely only the tip of the iceberg, clearly demonstrate the existence of central mechanisms that modulate browning, most likely by adjusting the sympathetic tone to WAT.

The immune system has only recently been implicated in browning. Initially, it was observed that macrophages in WAT can undergo alternative activation and

Published by Bioscientifica Ltd. 


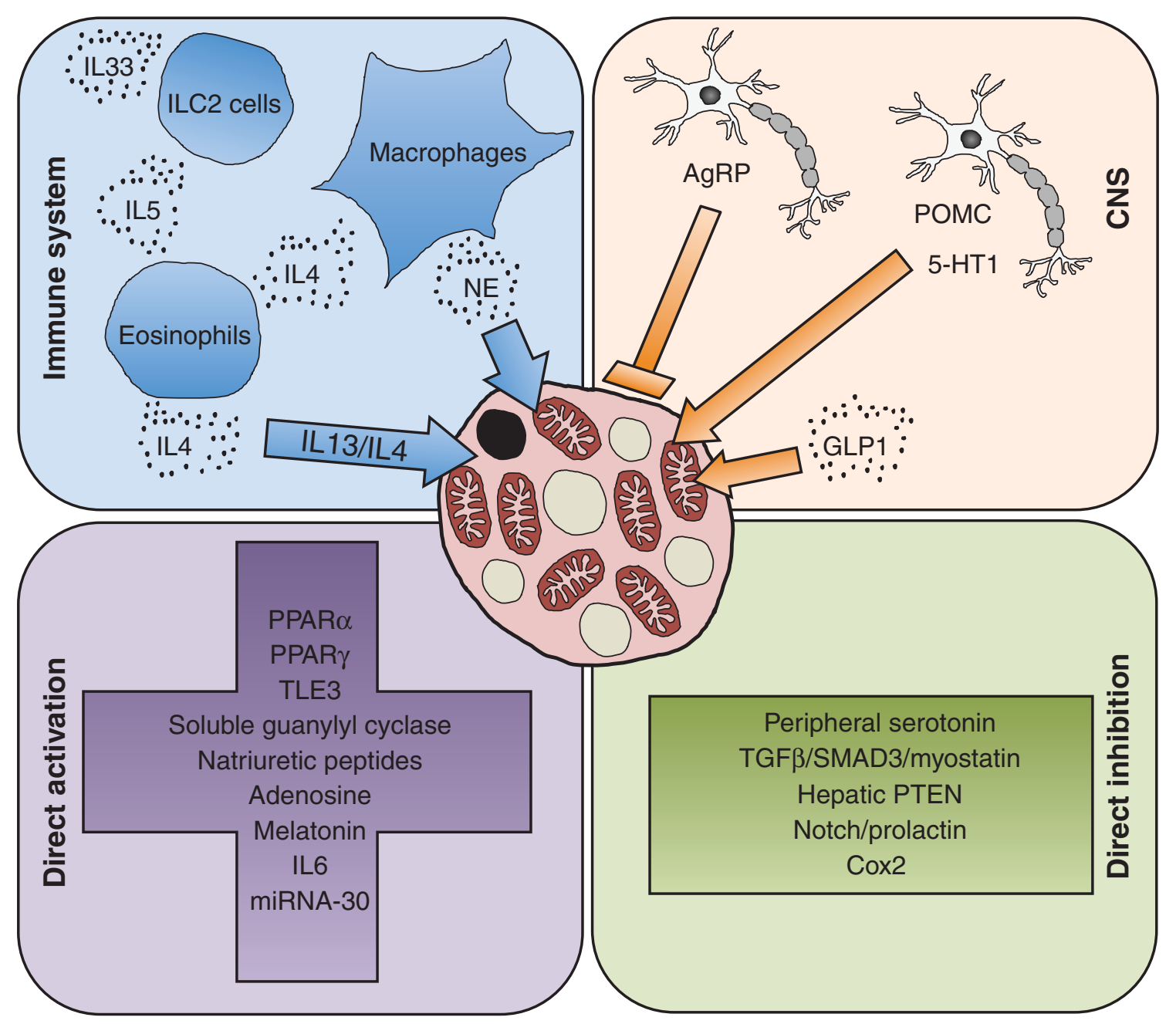

\section{Figure 1}

Different ways leading to browning of white adipose tissue, including immune system, CNS, direct activation, or direct inhibition. AgRP, agoutirelated peptide; Cox, cyclooxygenase; GLP1, glucagon-like peptide 1; IL, interleukin; ILC2 cells, type 2 innate lymphoid cells; miRNA, micro

begin to release catecholamines (Qiu et al. 2014), which triggers browning via pathways similar to sympathetic stimulation. Interestingly, cold-induced browning of WAT also appears to be dependent on the immune system, namely eosinophils and the interleukin 4 (IL4)/IL13 signaling pathway (Qiu et al. 2014). A more recent study shed more light on the underlying complex immunological pathways: when ILC2 immune cells are triggered by IL33, they produce IL5, which in turn activates eosinophils to release IL4. This subsequently activates macrophages to produce norepinephrine, which starts browning events in WAT. However, IL4 and IL13 seem to also have direct browning properties (Brestoff et al. 2015, Flach \& Diefenbach 2015, Lee et al. 2015). ribonucleic acid; POMC, proopiomelanocortin; PPAR, peroxisome proliferator-activated receptors; PTEN, phosphatase and tensin homolog; TGF, transforming growth factor; TLE3, transducin-like enhancer of split 3; 5-HT1, 5-hydroxytryptamine receptor 1 .

Most studies have identified mechanisms that directly cause browning of WAT, for instance, by activation of PPAR $\alpha$ (Rachid et al. 2015) or PPAR $\gamma$ (Petrovic et al. 2010), through FGF21 (Coskun et al. 2008), IL6 (Petruzzelli et al. 2014), natriuretic peptides (Bordicchia et al. 2012), adenosine through A2A receptors (Gnad et al. 2014), melatonin (Jimenez-Aranda et al. 2013), TLE3 (Villanueva et al. 2013), soluble guanylyl cyclase (Hoffmann et al. 2015), or even micro RNA such as miRNA30 (Hu et al. 2015). Unfortunately, the precise mechanisms are often unclear, and some of the identified candidates might well act through indirect mechanisms such as increasing sympathetic tone systemically, which leads to thermogenesis through $\beta$-adrenergic activation

Published by Bioscientifica Ltd 
(Bachman et al. 2002), or by altering body temperature through the promotion of heat loss (Warner et al. 2013). Moreover, at least for FGF21, it has been shown that some of the beneficial metabolic effects are in fact not dependent on UCP1 (Samms et al. 2015, Veniant et al. 2015).

In addition to these direct positive stimuli, a large number of pathways have been identified that seem to actively suppress browning. Consequently, the inhibition of these pathways in turn leads to the appearance of beige adipocytes. This includes peripheral serotonin levels (Crane et al. 2015), the TGF $\beta /$ SMAD3/myostatin cascade (Shan et al. 2013, Singh et al. 2014), hepatic PTEN (Peyrou et al. 2015), Notch or prolactin receptor signaling (Auffret et al. 2012, Bi et al. 2014), as well as Cox2 (Madsen et al. 2010).

\section{Do beige adipocytes contribute to whole body energy expenditure in rodents?}

Studies in vitro have shown that beige adipocytes have almost the same thermogenic potential as brown adipocytes (Shabalina et al. 2013). However, in rodents it is estimated that in vivo beige fat can only reach about $20 \%$ of the UCP1-dependent oxygen consumption per gram of tissue compared to canonical BAT, and the total mitochondrial mass of inguinal beige fat reaches at best $30 \%$ of the levels found in BAT (Shabalina et al. 2013). Likewise, the $\beta 3$-adrenergic-induced increase in glucose metabolism in pooled subcutaneous WAT of Zucker diabetic fatty rats was over 40 times less than in BAT (Liu et al. 1998). Whether recruited beige adipocytes can contribute significantly to whole-body energy expenditure in vivo therefore remains controversial, particularly since convincing direct measurements of its thermogenic contribution are currently lacking. There are three major reasons for this gap in knowledge: the complex relationship between BAT and browning of WAT, which clearly interfere with each other (Pan et al. 2014), the use of cold exposure and pharmacological agents such as $\beta 3$-adrenergic agonists, which act on both brown and beige fat in parallel, and the use of UCP1 mRNA as a readout of thermogenic activity (Nedergaard \& Cannon 2013).

The reporting of UCP1 mRNA expression as verification of significant browning and thermogenesis is a setback when determining whether browning of white fat is of functional relevance (Keipert \& Jastroch 2014, Jastroch \& Andersson 2015). As UCP1 mRNA expression is already relatively high in BAT at ambient temperature, further activation of BAT by cold exposure or pharmacological agent will only cause a modest increase in mRNA levels, which usually translates into a measurable change in tissue oxygen consumption and thermogenesis. In contrast, WAT depots such as inguinal or epididymal exhibit a very low and often very heterogeneous levels of baseline UCP1 mRNA expression (Wu et al. 2014), and any increase presented as fold elevation from virtually nothing can be a misrepresentation towards functional change (Nedergaard \& Cannon 2013). Consequently, absolute threshold cycle (CT) values should be reported (Keipert \& Jastroch 2014). In addition, increases in UCP1 mRNA expression do not necessarily translate to measurable UCP1 protein expression in subcutaneous and gonadal WAT, which becomes especially difficult in animals kept at thermoneutrality or in obese animals. Moreover, this is additionally confounded by the fact that many commercially available UCP1 antibodies detect proteins other than the target, often very close to the correct band weight, requiring optimal separation conditions and the need for a BAT lysate control (Veniant et al. 2015). Different blot exposure times between BAT and subcutaneous WAT are almost always needed, but usually not reported, giving the illusion that the presence of UCP1 is at a similar level when shown in the same figure. Consequently, when assessing browning of WAT, it is recommended to provide mRNA and protein data in direct comparison with BAT samples.

More importantly, alternative and additional readouts for thermogenesis should be provided to gain further insights into the biological relevance of the browning process at the tissue level. These alternatives could include tissue-specific substrate uptake studies using a variety of tracers, thereby determining functional significance by separating out the substrate uptake in each tissue in vivo without 'disrupting the system' (Bartelt et al. 2011, Khedoe et al. 2015, Kooijman et al. 2015). Using this approach, subcutaneous WAT has been shown to increase triglyceride uptake under cold exposure, although compared to BAT the effect was minimal (Bartelt et al. 2011). Moreover, blood flow to BAT and WAT depots can be an important indicator of metabolic function. The use of microspheres (Foster \& Frydman 1978, Rothwell \& Stock 1981) and more recently microbubbles (Baron et al. 2012) to measure blood flow, and therefore an approximation of oxygen consumption, can prove useful for measuring functional significance of individual tissues. Furthermore, more direct measurements of thermogenesis, for instance by recording tissue temperature (in relation to body and BAT temperature) through implantable transmitters or direct infrared thermography of fat pads, could shed light on the individual contributions to whole body thermogenesis.

Published by Bioscientifica Ltd 
However, here it needs to be taken into consideration that browning might be highly heterogeneous for the different WAT depots.

An alternative approach to discriminating BAT from beige fat thermogenesis could be the functional removal of interscapular brown fat via either chemical sympathectomy or physical denervation. However, this is not ideal as a means to study beige contribution, due to the ability of the other BAT depots to fully compensate (Rothwell \& Stock 1989). Moreover, in genetic models of BAT ablation it is difficult to separate true beige fat thermogenesis from developmental compensation, despite showing that browning of white fat is increased (Schulz et al. 2013).

As an opposite approach, transplantation of fat depots into recipient mice has proved successful in improving some metabolic parameters with BAT (Stanford et al. 2013, Liu et al. 2015), and to a lesser extent subcutaneous WAT into the visceral cavity (Tran et al. 2008). Also matrix assisted stem cell-derived beige fat transplantations generated some interesting effects (Tharp et al. 2015). Unfortunately, these approaches create very artificial situations, with yet unknown effects exerted by the donor tissue, including endocrine mechanisms, alterations of body temperature or other physiological parameters that are sensed by the brain and compensated for through changes in sympathetic tone, or even immune or stress responses. Consequently, detailed further studies potentially involving conditional beige vs BAT specific knockouts are urgently needed to delineate the respective individual contributions. This approach, however, requires detailed knowledge on brown and beige specific genes that can be used to drive tissue-specific manipulations.

Taken together, there is currently sparse evidence that beige fat contributes significantly to whole-body energy expenditure and thermogenesis under physiological conditions in rodents. Only under certain conditions, where for instance specific BAT depots are incapacitated or beige fat has been implanted, have significant actions been observed. Due to the issues previously indicated, this remains to be further validated.

\section{Role of thermogenic fat for weight loss in humans}

Owing to its capability to dissipate stored energy in the form of heat, there has been a renewed interest to use thermogenic fat for the treatment of obesity with the rediscovery of brown fat in the supraclavicular region of adult humans (van Marken Lichtenbelt et al. 2009, Virtanen et al. 2009). This brown fat depot seems to be highly variable, depending on gender, age, and ambient temperature (Cypess et al. 2015, Wang et al. $2015 a$ ). Moreover, it is still unclear whether this thermogenic fat is in fact brown, beige, or even a mixture of both (Wu et al. 2012, Jespersen et al. 2013), and whether the adipocytes are derived from $\mathrm{Myf}^{+}$precursors like true BAT or whether they are transdifferentiated white adipocytes. What is certain, however, is that these depots express UCP1 and have true thermogenic capacity, which can increase their uptake of circulating glucose and free fatty acids. They can also be activated by cold and $\beta 3$-adrenergic stimulation as well as by weight loss (Boon et al. 2015).

The most crucial point is whether the capacity for energy expenditure in these depots is high enough to shift energy expenditure compared to other means like exercise or food restriction (Fig. 2) and bring about tangible therapeutic benefits. First estimates from simple upscaling of rodent data suggested that a fully activated adult human BAT would burn about $300 \mathrm{kcal} / \mathrm{day}$, which would be a substantial contribution to the daily energy expenditure of a human. However, when factoring in tissue specific alterations in energy expenditure for species and size such as the Kleiber's law, the estimate would be around $50 \mathrm{kcal} /$ day for fully activated BAT (Devlin 2015). The first studies using real life conditions rather than algorithms now estimate that human BAT activated by mild cold exposure would contribute expenditure of 15-25 kcal/day (Muzik et al. 2013).

These findings are rather discouraging in the context of obesity treatment as an overweight person would require about 15 years of fully active BAT to melt off $20 \mathrm{~kg}$ of fat. This becomes even less feasible when considering that BAT is more difficult if not impossible to recruit in obese people (van Marken Lichtenbelt et al. 2009, Virtanen et al. 2009), highly variable between individuals (Cypess et al. 2009, Lee et al. 2013, Xue et al. 2015), and that any increase in energy expenditure is often met by increased compensatory food intake. More importantly, it is not sufficient to activate the BAT on a single occasion, as the additional thermogenesis will cease as soon as the individual returns to the usual thermoneutral environment, around $22^{\circ} \mathrm{C}$ for clothed humans. This was clearly demonstrated in a recent study, where BAT was activated by cold exposure $\left(15-16^{\circ} \mathrm{C}\right)$ for $6 \mathrm{~h}$ daily for 10 days, but resting metabolic rate was not elevated when the patients returned to thermoneutrality (van der Lans et al. 2013).

It can certainly be argued that if a conversion of additional human WAT depots to beige fat were possible,

Published by Bioscientifica Ltd. 


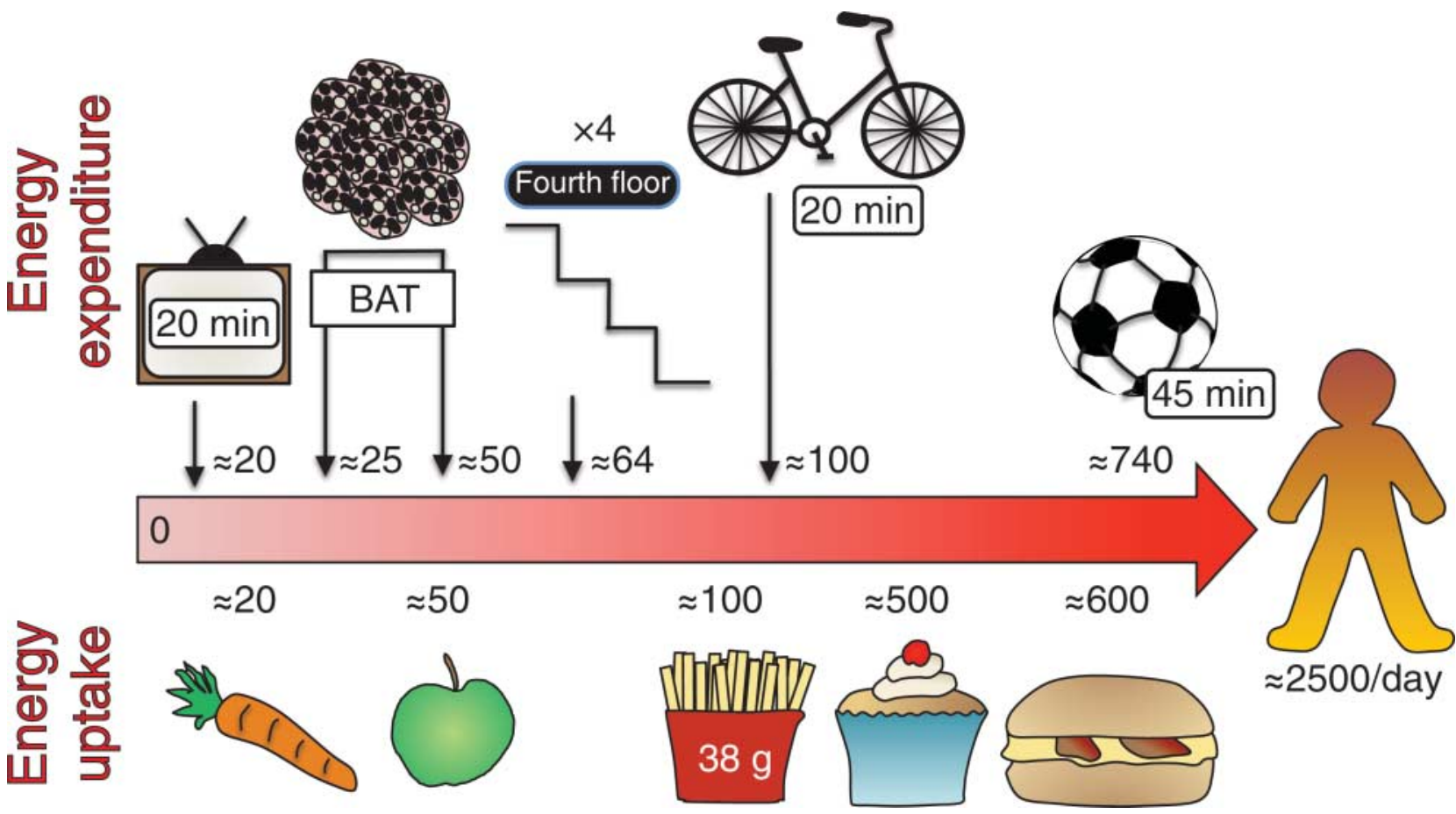

Figure 2

Estimated energy expenditure generated by fully activated human BAT (Muzik et al. 2013, Devlin 2015) in relation to other every day life events that concern energy uptake or expenditure in $\mathrm{kcal}$ (for a $75 \mathrm{~kg}$ person (Bassett et al. 1997, Gao et al. 2012)).

resulting in more thermogenic fat than in the supraclavicular region alone, this could substantially contribute to energy expenditure, especially in obese patients. Unfortunately, so far no significant beige adipocyte populations have been observed in the traditional WAT depots: UCP1 + cells were only observed in perirenal, visceral and subcutaneous fat of non obese children, but not at all in obese children or adults (Rockstroh et al. 2015). Likewise, mild cold exposure for 10 days did not induce browning in abdominal WAT (van der Lans et al. 2013). So far evidence of browning in humans has been observed only in extraordinary circumstances such as cachexia (Petruzzelli et al. 2014) or severe adrenergic stress through burns (Sidossis et al. 2015).

Therefore, it is currently uncertain how anatomical regions other than the supraclavicular depots can successfully be converted to thermogenic fat and how they can contribute significantly to overall energy expenditure.

\section{Pharmacological activation of human thermogenesis}

Emphasis on the activation of human thermogenesis to increase energy expenditure as a therapeutic intervention for obesity and related metabolic disorders such as type 2 diabetes is pervasive. While it might be questionable whether this approach could really be effective for weight loss, given the potentially low daily energy expenditure as previously mentioned and possible compensatory hyperphagia, the real benefit may lie in reducing circulating glucose and fatty acids, therefore increasing insulin sensitivity. Recent studies have shown that by increasing the volume of BAT through cold exposure, glucose clearance also improves (van der Lans et al. 2013, Chondronikola et al. 2014). However, this requires constant activation and substrate turnover of the BAT, as its storage capacity is limited. Most importantly, unwanted side effects must be considered, including increased sweating and hyperthermia, hunger and even cardiovascular problems, as UCP1 seems to have a negative effect on arterial plague formation (Dong et al. 2013). Consequently, well-controlled human studies are urgently required, if possible using several alternative strategies to assess BAT function, as the commonly used ${ }^{18}$ FDG-PET-CT technique measuring glucose uptake does not account for fatty acid oxidation, and the mechanism of preferential uptake between substrates is poorly understood (Townsend \& Tseng 2012).

The most obvious mechanisms to initiate thermogenesis in humans would be cold exposure or direct

Published by Bioscientifica Ltd 
$\beta 3$-adrenergic agonists. While recent studies have shown some promise (Cypess et al. 2009), $\beta 3$-adrenergic agonists have historically proven less effective in patients compared to rodents (Arch 2008), probably because the $\beta 3$-adrenergic signaling pathway is generally less sensitive in humans (Lafontan \& Berlan 1993), and cardiovascular side effects might be an issue. Consequently, many of the proposed activation strategies in rodents might ultimately fall short if they depend on $\beta 3$-adrenergic signaling. Conversely, cold exposure works impressively well, increasing energy expenditure and thermogenesis as well as the capacity for glucose clearance (van der Lans et al. 2013). However, this effect seems to require constant cold activation, as a return to thermoneutrality normalizes resting energy expenditure (Yoneshiro et al. 2011, van der Lans et al. 2013). Since constant cold exposure is somewhat uncomfortable for humans, pharmacological mechanisms that allow for permanent induction of thermogenesis could be favourable to keep the tissue in a constantly activated state. This would then circumvent any adaptational measures such as a reduced sympathetic tone in response to elevated body temperature, since it has been shown that browning can be reversed upon cold acclimation (Jankovic et al. 2015) and beige adipocytes can undergo 'whitening' again if not constantly activated (Rosenwald \& Wolfrum 2014).

\section{Problems in translating current rodent data}

There has been no shortage in recent publications demonstrating the induction of thermogenic fat in rodents. However, the precise mechanism is often unclear, and simply tipping the sensitive regulation of body temperature to hypothermia can already stimulate thermogenesis (Nedergaard \& Cannon 2014). This could include peripheral heat loss, changes in insulative capacity due to alterations in subcutaneous fat, skin or fur, or even behavioral changes that alter nesting. Additionally, many practical factors in experimental design affect the accurate measurement of thermogenesis in rodents, such as housing conditions, ambient temperature, and metabolic measurement (Virtue \& Vidal-Puig 2013, Xiao et al. 2015). Fortunately, studies are increasingly being conducted at both room temperature and thermoneutrality to discern true action of potential browning agents from other factors such as thermoregulatory compensation (Warner et al. 2013). Moreover, there are even distinct differences between different strains (Guerra et al. 1998, Li et al. 2014), age (Xue et al. 2007, Lasar et al. 2013) and adiposity (Kooijman et al. 2015), which affect the ability to induce beige fat in mice. Finally, several studies use doses that are at a high pharmacological level (Commins et al. 1999, Fisher et al. 2012, Wang et al. 2015b), which are likely to be unrealistic for use in humans.

The lack of the precise mechanism for the induction of thermogenesis will certainly hamper the translation of rodent data to the design of human studies, as a number of species differences are known between mice and humans that affect specific thermogenic systems. In addition to the aforementioned changes in $\beta 3$-adrenergic signaling, there are also differences for instance in the thermogenic response to food, the so-called diet-induced thermogenesis, between species. This phenomenon depends on BAT in rodents (Rothwell \& Stock 1981, Feldmann et al. 2009), but is still somewhat enigmatic in humans and may differ for different substrates (Schlogl et al. 2013). Moreover, adult human thermogenic fat does not share the same gene expression profile as either rodent BAT or beige fat, with current data suggesting that it could even be a mixture of both types, with the deepest neck areas possessing the most brown fat characteristics and displaying the highest expression of UCP1 (Park et al. 2015).

\section{The future of beige adipocytes}

Despite an overwhelming number of comprehensive studies on thermogenic fat in humans and browning of white fat in rodents, several issues still remain enigmatic: What exactly is the thermogenic fat in adult humans? Where does it come from? Which mechanisms activate and deactivate it? How does it compare to BAT or beige fat in rodents? Moreover, it remains uncertain what the role for beige fat is in rodents, especially as there is accumulating evidence that the thermogenic contribution might be insignificant. Could it be that beige fat constitutes some kind of thermogenic appendix, given that UCP1 evolved before a specialized tissue for thermogenesis such as BAT existed (Nedergaard \& Cannon 1990, Oelkrug et al. 2015)? While white fat expressing UCP1 might certainly be an advantage in the absence of functional BAT (Schulz et al. 2013) and sufficient fuel would also be available from surrounding WAT depots, it still would require some time to recruit this tissue for thermogenesis given the relatively low capacity of available mitochondria. Alternatively, one could also speculate that beige fat might have a different physiological function than thermogenesis. This is supported by the fact that it can be induced by exercise (Bostrom et al. 2012, Stanford et al. 2013, Rao et al. 2014),

Published by Bioscientifica Ltd. 
which is a condition where thermogenesis is certainly not needed and might even be counterproductive, or by thyrotoxicosis, a condition where body temperature is already elevated by the increased basal metabolic rate (Obregon 2014).

Finally, the big questions: which of the rodent mechanisms are also applicable to the human condition, and which mechanisms really unlock the true metabolic potential of thermogenesis without severe side effects? Here a vast number of agents capable of browning by several different means under very specific circumstances must be considered. Unfortunately for many of these agents, the underlying mechanisms are unclear and might turn out to be a consequence of reducing body temperature or activating the immune system. Furthermore, alternative strategies aiming at activating brown (not beige) fat in rodents through for instance hypothalamic AMPK activation (Lopez et al. 2010) or reducing body temperature by increasing heat loss (Warner \& Mittag 2014), might provide more successful strategies for metabolic improvement. However, additional more comprehensive studies aiming to address these issues are therefore urgently needed to facilitate the translation of rodent thermogenesis for human metabolic health.

\section{Declaration of interest}

A W is an employee of AstraZeneca AB. J M has no conflict of interest to declare.

\section{Funding}

This work was supported by the Deutsche Forschungsgemeinschaft (Heisenberg Program Mi1242/2-1 to J M).

\section{Acknowledgements}

We thank Drs Rebecca Ölkrug and Daniel Lindén for critical comments on the manuscript.

\section{References}

Arch JR 2008 The discovery of drugs for obesity, the metabolic effects of leptin and variable receptor pharmacology: perspectives from $\beta 3$-adrenoceptor agonists. Naunyn-Schmiedeberg's Archives of Pharmacology 378 225-240. (doi:10.1007/s00210-008-0271-1)

Asano H, Kanamori Y, Higurashi S, Nara T, Kato K, Matsui T \& Funaba M 2014 Induction of beige-like adipocytes in 3T3-L1 cells. Journal of Veterinary Medical Science 76 57-64. (doi:10.1292/jvms.13-0359)

Auffret J, Viengchareun S, Carre N, Denis RG, Magnan C, Marie PY, Muscat A, Feve B, Lombes M \& Binart N 2012 Beige differentiation of adipose depots in mice lacking prolactin receptor protects against high-fat-diet-induced obesity. FASEB Journal 26 3728-3737. (doi:10.1096/fj.12-204958)
Bachman ES, Dhillon H, Zhang CY, Cinti S, Bianco AC, Kobilka BK \& Lowell BB $2002 \beta A R$ signaling required for diet-induced thermogenesis and obesity resistance. Science 297 843-845. (doi:10.1126/science.1073160)

Baron DM, Clerte M, Brouckaert P, Raher MJ, Flynn AW, Zhang H, Carter EA, Picard MH, Bloch KD, Buys ES et al. 2012 In vivo noninvasive characterization of brown adipose tissue blood flow by contrast ultrasound in mice. Circulation. Cardiovascular Imaging 5 652-659. (doi:10.1161/CIRCIMAGING.112.975607)

Bartelt A \& Heeren J 2014 Adipose tissue browning and metabolic health. Nature Reviews. Endocrinology 10 24-36. (doi:10.1038/nrendo.2013.204)

Bartelt A, Bruns OT, Reimer R, Hohenberg H, Ittrich H, Peldschus K, Kaul MG, Tromsdorf UI, Weller H, Waurisch C et al. 2011 Brown adipose tissue activity controls triglyceride clearance. Nature Medicine 17 200-205. (doi:10.1038/nm.2297)

Bassett DR, Vachon JA, Kirkland AO, Howley ET, Duncan GE \& Johnson KR 1997 Energy cost of stair climbing and descending on the college alumnus questionnaire. Medicine and Science in Sports and Exercise 29 1250-1254. (doi:10.1097/00005768-199709000-00019)

Beiroa D, Imbernon M, Gallego R, Senra A, Herranz D, Villarroya F, Serrano M, Ferno J, Salvador J, Escalada J et al. 2014 GLP-1 agonism stimulates brown adipose tissue thermogenesis and browning through hypothalamic AMPK. Diabetes 63 3346-3358. (doi:10.2337/db14-0302)

Bi P, Shan T, Liu W, Yue F, Yang X, Liang XR, Wang J, Li J, Carlesso N, Liu X et al. 2014 Inhibition of Notch signaling promotes browning of white adipose tissue and ameliorates obesity. Nature Medicine 20 911-918. (doi:10.1038/nm.3615)

Boon MR, Nascimento EB \& van Marken Lichtenbelt WD 2015 Tracing human brown fat. Nature Medicine 21 667-668. (doi:10.1038/nm.3900)

Bordicchia M, Liu D, Amri EZ, Ailhaud G, Dessi-Fulgheri P, Zhang C, Takahashi N, Sarzani R \& Collins S 2012 Cardiac natriuretic peptides act via p38 MAPK to induce the brown fat thermogenic program in mouse and human adipocytes. Journal of Clinical Investigation 122 1022-1036. (doi:10.1172/JCI59701)

Bostrom P, Wu J, Jedrychowski MP, Korde A, Ye L, Lo JC, Rasbach KA, Bostrom EA, Choi JH, Long JZ et al. 2012 A PGC1- $\alpha$-dependent myokine that drives brown-fat-like development of white fat and thermogenesis. Nature 481 463-468. (doi:10.1038/nature10777)

Brestoff JR, Kim BS, Saenz SA, Stine RR, Monticelli LA, Sonnenberg GF, Thome JJ, Farber DL, Lutfy K, Seale P et al. 2015 Group 2 innate lymphoid cells promote beiging of white adipose tissue and limit obesity. Nature 519 242-246. (doi:10.1038/nature14115)

Cannon B \& Nedergaard J 2004 Brown adipose tissue: function and physiological significance. Physiological Reviews 84 277-359. (doi:10.1152/physrev.00015.2003)

Carey AL, Vorlander C, Reddy-Luthmoodoo M, Natoli AK, Formosa MF, Bertovic DA, Anderson MJ, Duffy SJ \& Kingwell BA 2014 Reduced UCP-1 content in in vitro differentiated beige/brite adipocytes derived from preadipocytes of human subcutaneous white adipose tissues in obesity. PLoS ONE 9 e91997. (doi:10.1371/journal.pone.0091997)

Chondronikola M, Volpi E, Borsheim E, Porter C, Annamalai P, Enerback S, Lidell ME, Saraf MK, Labbe SM, Hurren NM et al. 2014 Brown adipose tissue improves whole-body glucose homeostasis and insulin sensitivity in humans. Diabetes 63 4089-4099. (doi:10.2337/db14-0746)

Commins SP, Watson PM, Padgett MA, Dudley A, Argyropoulos G \& Gettys TW 1999 Induction of uncoupling protein expression in brown and white adipose tissue by leptin. Endocrinology 140 292-300. (doi:10.1210/endo.140.1.6399)

Coskun T, Bina HA, Schneider MA, Dunbar JD, Hu CC, Chen Y, Moller DE $\&$ Kharitonenkov A 2008 Fibroblast growth factor 21 corrects obesity in mice. Endocrinology 149 6018-6027. (doi:10.1210/en.2008-0816)

Crane JD, Palanivel R, Mottillo EP, Bujak AL, Wang H, Ford RJ, Collins A, Blumer RM, Fullerton MD, Yabut JM et al. 2015 Inhibiting peripheral serotonin synthesis reduces obesity and metabolic dysfunction by promoting brown adipose tissue thermogenesis. Nature Medicine 21 166-172. (doi:10.1038/nm.3766) 
Cypess AM, Lehman S, Williams G, Tal I, Rodman D, Goldfine AB, Kuo FC, Palmer EL, Tseng YH, Doria A et al. 2009 Identification and importance of brown adipose tissue in adult humans. New England Journal of Medicine 360 1509-1517. (doi:10.1056/NEJMoa0810780)

Cypess AM, Weiner LS, Roberts-Toler C, Franquet Elia E, Kessler SH, Kahn PA, English J, Chatman K, Trauger SA, Doria A et al. 2015 Activation of human brown adipose tissue by a $\beta 3$-adrenergic receptor agonist. Cell Metabolism 21 33-38. (doi:10.1016/j.cmet.2014.12.009)

Devlin MJ 2015 The "Skinny" on brown fat, obesity, and bone. American Journal of Physical Anthropology 156(Suppl 59) 98-115. (doi:10.1002/ ajpa.22661)

Dodd GT, Decherf S, Loh K, Simonds SE, Wiede F, Balland E, Merry TL, Munzberg H, Zhang ZY, Kahn BB et al. 2015 Leptin and insulin act on POMC neurons to promote the browning of white fat. Cell 160 88-104. (doi:10.1016/j.cell.2014.12.022)

Dong M, Yang X, Lim S, Cao Z, Honek J, Lu H, Zhang C, Seki T, Hosaka K, Wahlberg E et al. 2013 Cold exposure promotes atherosclerotic plaque growth and instability via UCP1-dependent lipolysis. Cell Metabolism 18 118-129. (doi:10.1016/j.cmet.2013.06.003)

Emont MP, Yu H \& Wu J 2015 Transcriptional control and hormonal response of thermogenic fat. Journal of Endocrinology 225 R35-R47. (doi:10.1530/JOE-15-0026)

Feldmann HM, Golozoubova V, Cannon B \& Nedergaard J 2009 UCP1 ablation induces obesity and abolishes diet-induced thermogenesis in mice exempt from thermal stress by living at thermoneutrality. Cell Metabolism 9 203-209. (doi:10.1016/j.cmet.2008.12.014)

Fisher FM, Kleiner S, Douris N, Fox EC, Mepani RJ, Verdeguer F, Wu J, Kharitonenkov A, Flier JS, Maratos-Flier E et al. 2012 FGF21 regulates PGC- $1 \alpha$ and browning of white adipose tissues in adaptive thermogenesis. Genes and Development 26 271-281. (doi:10.1101/ gad.177857.111)

Flach M \& Diefenbach A 2015 Adipose tissue: ILC2 crank up the heat. Cell Metabolism 21 152-153. (doi:10.1016/j.cmet.2015.01.015)

Foster DO \& Frydman ML 1978 Nonshivering thermogenesis in the rat. II. Measurements of blood flow with microspheres point to brown adipose tissue as the dominant site of the calorigenesis induced by noradrenaline. Canadian Journal of Physiology and Pharmacology 56 110122. (doi:10.1139/y78-015)

Gao Z, Wang X, Zhuo Q, Wang J, Hu F, Piao J, Liu F \& Cao H 2012 Energy expenditure on different physical activities of rural adults in North China. Wei Sheng Yan Jiu 41 75-79.

Gnad T, Scheibler S, von Kugelgen I, Scheele C, Kilic A, Glode A, Hoffmann LS, Reverte-Salisa L, Horn P, Mutlu S et al. 2014 Adenosine activates brown adipose tissue and recruits beige adipocytes via A2A receptors. Nature 516 395-399. (doi:10.1038/nature13816)

Guerra C, Koza RA, Yamashita H, Walsh K \& Kozak LP 1998 Emergence of brown adipocytes in white fat in mice is under genetic control. Effects on body weight and adiposity. Journal of Clinical Investigation 102 412-420. (doi:10.1172/JCI3155)

Hoffmann LS, Etzrodt J, Willkomm L, Sanyal A, Scheja L, Fischer AW, Stasch JP, Bloch W, Friebe A, Heeren J et al. 2015 Stimulation of soluble guanylyl cyclase protects against obesity by recruiting brown adipose tissue. Nature Communications 6 7235. (doi:10.1038/ncomms8235)

Hu F, Wang M, Xiao T, Yin B, He L, Meng W, Dong M \& Liu F 2015 miR-30 promotes thermogenesis and the development of beige fat by targeting RIP140. Diabetes 64 2056-2068. (doi:10.2337/db14-1117)

Huang-Doran I, Sleigh A, Rochford JJ, O'Rahilly S \& Savage DB 2010 Lipodystrophy: metabolic insights from a rare disorder. Journal of Endocrinology 207 245-255. (doi:10.1677/JOE-10-0272)

Jankovic A, Golic I, Markelic M, Stancic A, Otasevic V, Buzadzic B, Korac A \& Korac B 2015 Two key temporally distinguishable molecular and cellular components of white adipose tissue browning during cold acclimation. Journal of Physiology 593 3267-3280. (doi:10.1113/ JP270805)

Jastroch M \& Andersson L 2015 When pigs fly, UCP1 makes heat. Molecular Metabolism 4 359-362. (doi:10.1016/j.molmet.2015.02.005)
Jespersen NZ, Larsen TJ, Peijs L, Daugaard S, Homoe P, Loft A, de Jong J, Mathur N, Cannon B, Nedergaard J et al. 2013 A classical brown adipose tissue mRNA signature partly overlaps with brite in the supraclavicular region of adult humans. Cell Metabolism 17 798-805. (doi:10.1016/j. cmet.2013.04.011)

Jimenez-Aranda A, Fernandez-Vazquez G, Campos D, Tassi M, Velasco-Perez L, Tan DX, Reiter RJ \& Agil A 2013 Melatonin induces browning of inguinal white adipose tissue in Zucker diabetic fatty rats. Journal of Pineal Research 55 416-423. (doi:10.1111/jpi.12089)

Keipert S \& Jastroch M 2014 Brite/beige fat and UCP1 - is it thermogenesis? Biochimica et Biophysica Acta 1837 1075-1082. (doi:10.1016/j.bbabio. 2014.02.008)

Khedoe PP, Hoeke G, Kooijman S, Dijk W, Buijs JT, Kersten S, Havekes LM, Hiemstra PS, Berbee JF, Boon MR et al. 2015 Brown adipose tissue takes up plasma triglycerides mostly after lipolysis. Journal of Lipid Research 56 51-59. (doi:10.1194/jlr.M052746)

Kooijman S, Wang Y, Parlevliet ET, Boon MR, Edelschaap D, Snaterse G, Pijl H, Romijn JA \& Rensen PC 2015 Central GLP-1 receptor signalling accelerates plasma clearance of triacylglycerol and glucose by activating brown adipose tissue in mice. Diabetologia 58 2637-2646. (doi:10.1007/ s00125-015-3727-0)

Lafontan M \& Berlan M 1993 Fat cell adrenergic receptors and the control of white and brown fat cell function. Journal of Lipid Research $\mathbf{3 4}$ 1057-1091.

van der Lans AA, Hoeks J, Brans B, Vijgen GH, Visser MG, Vosselman MJ, Hansen J, Jorgensen JA, Wu J, Mottaghy FM et al. 2013 Cold acclimation recruits human brown fat and increases nonshivering thermogenesis. Journal of Clinical Investigation 123 3395-3403. (doi:10.1172/JCI68993)

Lasar D, Julius A, Fromme T \& Klingenspor M 2013 Browning attenuates murine white adipose tissue expansion during postnatal development. Biochimica et Biophysica Acta 1831 960-968. (doi:10.1016/j.bbalip.2013. 01.016)

Lee P, Swarbrick MM \& Ho KK 2013 Brown adipose tissue in adult humans: a metabolic renaissance. Endocrine Reviews 34 413-438. (doi:10.1210/er. 2012-1081)

Lee MW, Odegaard JI, Mukundan L, Qiu Y, Molofsky AB, Nussbaum JC, Yun K, Locksley RM \& Chawla A 2015 Activated type 2 innate lymphoid cells regulate beige fat biogenesis. Cell 160 74-87. (doi:10.1016/i.cell. 2014.12.011)

Li Y, Bolze F, Fromme T \& Klingenspor M 2014 Intrinsic differences in BRITE adipogenesis of primary adipocytes from two different mouse strains. Biochimica et Biophysica Acta 1841 1345-1352. (doi:10.1016/ j.bbalip.2014.06.003)

Liu X, Perusse F \& Bukowiecki LJ 1998 Mechanisms of the antidiabetic effects of the $\beta 3$-adrenergic agonist CL-316243 in obese Zucker-ZDF rats. American Journal of Physiology 274 R1212-R1219.

Liu X, Wang S, You Y, Meng M, Zheng Z, Dong M, Lin J, Zhao Q, Zhang C, Yuan $X$ et al. 2015 Brown adipose tissue transplantation reverses obesity in Ob/Ob mice. Endocrinology 156 2461-2469. (doi:10.1210/ en.2014-1598)

Lobstein T, Jackson-Leach R, Moodie ML, Hall KD, Gortmaker SL, Swinburn BA, James WP, Wang Y \& McPherson K 2015 Child and adolescent obesity: part of a bigger picture. Lancet 385 2510-2520 (doi:10.1016/S0140-6736(14)61746-3)

Long JZ, Svensson KJ, Tsai L, Zeng X, Roh HC, Kong X, Rao RR, Lou J, Lokurkar I, Baur W et al. 2014 A smooth muscle-like origin for beige adipocytes. Cell Metabolism 19 810-820. (doi:10.1016/j.cmet. 2014.03.025)

Lopez M, Varela L, Vazquez MJ, Rodriguez-Cuenca S, Gonzalez CR, Velagapudi VR, Morgan DA, Schoenmakers E, Agassandian K, Lage R et al. 2010 Hypothalamic AMPK and fatty acid metabolism mediate thyroid regulation of energy balance. Nature Medicine 16 1001-1008. (doi:10.1038/nm.2207)

Published by Bioscientifica Ltd. 
Lopez M, Dieguez C \& Nogueiras R 2015 Hypothalamic GLP-1: the control of BAT thermogenesis and browning of white fat. Adipocyte 4 141-145. (doi:10.4161/21623945.2014.983752)

Madsen L, Pedersen LM, Lillefosse HH, Fjaere E, Bronstad I, Hao Q Petersen RK, Hallenborg P, Ma T, De Matteis R et al. 2010 UCP1 induction during recruitment of brown adipocytes in white adipose tissue is dependent on cyclooxygenase activity. PLOS ONE 5 e11391. (doi:10.1371/journal.pone.0011391)

van Marken Lichtenbelt WD, Vanhommerig JW, Smulders NM, Drossaerts JM, Kemerink GJ, Bouvy ND, Schrauwen P \& Teule GJ 2009 Cold-activated brown adipose tissue in healthy men. New England Journal of Medicine 360 1500-1508. (doi:10.1056/NEJMoa0808718)

McGlashon JM, Gorecki MC, Kozlowski AE, Thirnbeck CK, Markan KR, Leslie KL, Kotas ME, Potthoff MJ, Richerson GB \& Gillum MP 2015 Central serotonergic neurons activate and recruit thermogenic brown and beige fat and regulate glucose and lipid homeostasis. Cell Metabolism 21 692-705. (doi:10.1016/j.cmet.2015.04.008)

Muzik O, Mangner TJ, Leonard WR, Kumar A, Janisse J \& Granneman JG $2013{ }^{15}$ O PET measurement of blood flow and oxygen consumption in cold-activated human brown fat. Journal of Nuclear Medicine $\mathbf{5 4}$ 523-531. (doi:10.2967/jnumed.112.111336)

Nedergaard J \& Cannon B 1990 Mammalian hibernation. Philosophical Transactions of the Royal Society of London. Series B, Biological Sciences 326 669-685 (discussion 685-686). (doi:10.1098/rstb.1990.0038)

Nedergaard J \& Cannon B 2013 UCP1 mRNA does not produce heat. Biochimica et Biophysica Acta 1831 943-949. (doi:10.1016/j.bbalip.2013. 01.009)

Nedergaard J \& Cannon B 2014 The browning of white adipose tissue: some burning issues. Cell Metabolism 20 396-407. (doi:10.1016/j.cmet.2014. 07.005)

Obregon MJ 2014 Adipose tissues and thyroid hormones. Frontiers in Physiology 5 479. (doi:10.3389/fphys.2014.00479)

Oelkrug R, Polymeropoulos ET \& Jastroch M 2015 Brown adipose tissue: physiological function and evolutionary significance. Journal of Comparative Physiology. B, Biochemical, Systemic, and Environmental Physiology 185 587-606. (doi:10.1007/s00360-015-0907-7)

Okamatsu-Ogura Y, Fukano K, Tsubota A, Uozumi A, Terao A, Kimura K \& Saito M 2013 Thermogenic ability of uncoupling protein 1 in beige adipocytes in mice. PLOS ONE 8 e84229. (doi:10.1371/journal.pone. 0084229)

Pan D, Mao C, Quattrochi B, Friedline RH, Zhu LJ, Jung DY, Kim JK, Lewis B \& Wang YX 2014 MicroRNA-378 controls classical brown fat expansion to counteract obesity. Nature Communications 5 4725. (doi:10.1038/ ncomms5725)

Park JH, Hur W \& Lee SB 2015 Intricate transcriptional networks of classical brown and beige fat cells. Frontiers in Endocrinology 6 124. (doi:10.3389/ fendo.2015.00124)

Petrovic N, Walden TB, Shabalina IG, Timmons JA, Cannon B \& Nedergaard J 2010 Chronic peroxisome proliferator-activated receptor gamma (PPARgamma) activation of epididymally derived white adipocyte cultures reveals a population of thermogenically competent, UCP1-containing adipocytes molecularly distinct from classic brown adipocytes. Journal of Biological Chemistry 285 7153-7164. (doi:10.1074/ jbc.M109.053942)

Petruzzelli M, Schweiger M, Schreiber R, Campos-Olivas R, Tsoli M, Allen J, Swarbrick M, Rose-John S, Rincon M, Robertson G et al. 2014 A switch from white to brown fat increases energy expenditure in cancerassociated cachexia. Cell Metabolism 20 433-447. (doi:10.1016/j.cmet. 2014.06.011)

Peyrou M, Bourgoin L, Poher AL, Altirriba J, Maeder C, Caillon A, Fournier M, Montet X, Rohner-Jeanrenaud F \& Foti M 2015 Hepatic PTEN deficiency improves muscle insulin sensitivity and decreases adiposity in mice. Journal of Hepatology 62 421-429. (doi:10.1016/ j.jhep.2014.09.012)

Qiu Y, Nguyen KD, Odegaard JI, Cui X, Tian X, Locksley RM, Palmiter RD \& Chawla A 2014 Eosinophils and type 2 cytokine signaling in macrophages orchestrate development of functional beige fat. Cell $\mathbf{1 5 7}$ 1292-1308. (doi:10.1016/j.cell.2014.03.066)

Rachid TL, Penna-de-Carvalho A, Bringhenti I, Aguila MB, Mandarim-deLacerda CA \& Souza-Mello V 2015 Fenofibrate (PPAR $\alpha$ agonist) induces beige cell formation in subcutaneous white adipose tissue from diet-induced male obese mice. Molecular and Cellular Endocrinology 402 86-94. (doi:10.1016/j.mce.2014.12.027)

Rajakumari S, Wu J, Ishibashi J, Lim HW, Giang AH, Won KJ, Reed RR \& Seale P 2013 EBF2 determines and maintains brown adipocyte identity. Cell Metabolism 17 562-574. (doi:10.1016/j.cmet.2013.01.015)

Rao RR, Long JZ, White JP, Svensson KJ, Lou J, Lokurkar I, Jedrychowski MP, Ruas JL, Wrann CD, Lo JC et al. 2014 Meteorin-like is a hormone that regulates immune-adipose interactions to increase beige fat thermogenesis. Cell 157 1279-1291. (doi:10.1016/j.cell.2014.03.065)

Rockstroh D, Landgraf K, Wagner I, Gesing J, Tauscher R, Lakowa N, Kiess W, Bühligen U, Wojan M, Till H et al. 2015 Direct evidence of brown adipocytes in different fat depots in children. PLOS ONE 10 e0117841. (doi:10.1371/journal.pone.0117841)

Rosenwald M \& Wolfrum C 2014 The origin and definition of brite versus white and classical brown adipocytes. Adipocyte 3 4-9. (doi:10.4161/ adip.26232)

Rothwell NJ \& Stock MJ 1981 Influence of noradrenaline on blood flow to brown adipose tissue in rats exhibiting diet-induced thermogenesis. Pflügers Archiv: European Journal of Physiology 389 237-242. (doi:10.1007/BF00584784)

Rothwell NJ \& Stock MJ 1989 Surgical removal of brown fat results in rapid and complete compensation by other depots. American Journal of Physiology 257 R253-R258.

Ruan HB, Dietrich MO, Liu ZW, Zimmer MR, Li MD, Singh JP, Zhang K, Yin R, Wu J, Horvath TL et al. 2014 O-GlcNAc transferase enables AgRP neurons to suppress browning of white fat. Cell 159 306-317. (doi:10.1016/j.cell.2014.09.010)

Sacks HS, Fain JN, Bahouth SW, Ojha S, Frontini A, Budge H, Cinti S \& Symonds ME 2013 Adult epicardial fat exhibits beige features. Journal of Clinical Endocrinology and Metabolism 98 E1448-E1455. (doi:10.1210/jc. 2013-1265)

Samms RJ, Smith DP, Cheng CC, Antonellis PP, Perfield JW II, Kharitonenkov A, Gimeno RE \& Adams AC 2015 Discrete aspects of FGF21 in vivo pharmacology do not require UCP1. Cell Reports 11 991-999. (doi:10.1016/j.celrep.2015.04.046)

Sanchez-Gurmaches J \& Guertin DA 2014 Adipocyte lineages: tracing back the origins of fat. Biochimica et Biophysica Acta 1842 340-351. (doi:10.1016/j.bbadis.2013.05.027)

Schlogl M, Piaggi P, Thiyyagura P, Reiman EM, Chen K, Lutrin C, Krakoff J \& Thearle MS 2013 Overfeeding over 24 hours does not activate brown adipose tissue in humans. Journal of Clinical Endocrinology and Metabolism 98 E1956-E1960. (doi:10.1210/jc.2013-2387)

Schulz TJ, Huang P, Huang TL, Xue R, McDougall LE, Townsend KL, Cypess AM, Mishina Y, Gussoni E \& Tseng YH 2013 Brown-fat paucity due to impaired BMP signalling induces compensatory browning of white fat. Nature 495 379-383. (doi:10.1038/nature11943)

Seale P, Bjork B, Yang W, Kajimura S, Chin S, Kuang S, Scime A, Devarakonda S, Conroe HM, Erdjument-Bromage H et al. 2008 PRDM16 controls a brown fat/skeletal muscle switch. Nature 454 961-967. (doi:10.1038/nature07182)

Shabalina IG, Petrovic N, de Jong JM, Kalinovich AV, Cannon B \& Nedergaard J 2013 UCP1 in brite/beige adipose tissue mitochondria is functionally thermogenic. Cell Reports 5 1196-1203. (doi:10.1016/j. celrep.2013.10.044)

Shan T, Liang X, Bi P \& Kuang S 2013 Myostatin knockout drives browning of white adipose tissue through activating the AMPK-PGC1 $\alpha-$ Fndc5 pathway in muscle. FASEB Journal 27 1981-1989. (doi:10.1096/fj.12225755)

Sidossis L \& Kajimura S 2015 Brown and beige fat in humans: thermogenic adipocytes that control energy and glucose homeostasis. Journal of Clinical Investigation 125 478-486. (doi:10.1172/JCI78362) 
Sidossis LS, Porter C, Saraf MK, Borsheim E, Radhakrishnan RS, Chao T, Ali A, Chondronikola M, Mlcak R, Finnerty CC et al. 2015 Browning of subcutaneous white adipose tissue in humans after severe adrenergic stress. Cell Metabolism 22 219-227. (doi:10.1016/j.cmet. 2015.06.022)

Singh R, Braga M \& Pervin S 2014 Regulation of brown adipocyte metabolism by myostatin/follistatin signaling. Frontiers in Cell and Developmental Biology 2 60. (doi:10.3389/fcell.2014.00060)

Speakman JR \& O'Rahilly S 2012 Fat: an evolving issue. Disease Models \& Mechanisms 5 569-573. (doi:10.1242/dmm.010553)

Stanford KI, Middelbeek RJ, Townsend KL, An D, Nygaard EB, Hitchcox KM, Markan KR, Nakano K, Hirshman MF, Tseng YH et al. 2013 Brown adipose tissue regulates glucose homeostasis and insulin sensitivity. Journal of Clinical Investigation 123 215-223. (doi:10.1172/JCI62308)

Symonds ME, Pope M \& Budge H 2015 The ontogeny of brown adipose tissue. Annual Review of Nutrition 35 295-320. (doi:10.1146/annurevnutr-071813-105330)

Tharp KM, Jha AK, Kraiczy J, Yesian A, Karateev G, Sinisi R, Dubikovskaya EA, Healy KE \& Stahl A 2015 Matrix assisted transplantation of functional beige adipose tissue. Diabetes 64 3713-3724 (doi:10.2337/db15-0728)

Townsend K \& Tseng YH 2012 Brown adipose tissue: Recent insights into development, metabolic function and therapeutic potential. Adipocyte 1 13-24. (doi:10.4161/adip.18951)

Tran TT, Yamamoto Y, Gesta S \& Kahn CR 2008 Beneficial effects of subcutaneous fat transplantation on metabolism. Cell Metabolism 7 410-420. (doi:10.1016/j.cmet.2008.04.004)

Tseng YH, Kokkotou E, Schulz TJ, Huang TL, Winnay JN, Taniguchi CM, Tran TT, Suzuki R, Espinoza DO, Yamamoto Y et al. 2008 New role of bone morphogenetic protein 7 in brown adipogenesis and energy expenditure. Nature 454 1000-1004. (doi:10.1038/nature07221)

Uldry M, Yang W, St-Pierre J, Lin J, Seale P \& Spiegelman BM 2006 Complementary action of the PGC-1 coactivators in mitochondrial biogenesis and brown fat differentiation. Cell Metabolism 3 333-341. (doi:10.1016/j.cmet.2006.04.002)

Veniant MM, Sivits G, Helmering J, Komorowski R, Lee J, Fan W, Moyer C \& Lloyd DJ 2015 Pharmacologic effects of FGF21 are independent of the "browning" of white adipose tissue. Cell Metabolism 21 731-738. (doi:10.1016/j.cmet.2015.04.019)

Villanueva CJ, Vergnes L, Wang J, Drew BG, Hong C, Tu Y, Hu Y, Peng X, $\mathrm{Xu}$ F, Saez E et al. 2013 Adipose subtype-selective recruitment of TLE3 or Prdm16 by PPARgamma specifies lipid storage versus thermogenic gene programs. Cell Metabolism 17 423-435. (doi:10.1016/ j.cmet.2013.01.016)

Virtanen KA, Lidell ME, Orava J, Heglind M, Westergren R, Niemi T, Taittonen M, Laine J, Savisto NJ, Enerback S et al. 2009 Functional brown adipose tissue in healthy adults. New England Journal of Medicine 360 1518-1525. (doi:10.1056/NEJMoa0808949)

Virtue S \& Vidal-Puig A 2013 Assessment of brown adipose tissue function. Frontiers in Physiology 4 128. (doi:10.3389/fphys.2013.00128)

Wang Q, Zhang M, Xu M, Gu W, Xi Y, Qi L, Li B \& Wang W 2015a Brown adipose tissue activation is inversely related to central obesity and metabolic parameters in adult human. PLOS ONE 10 e0123795. (doi:10.1371/journal.pone.0123795)

Wang S, Wang X, Ye Z, Xu C, Zhang M, Ruan B, Wei M, Jiang Y, Zhang Y, Wang L et al. $2015 b$ Curcumin promotes browning of white adipose tissue in a norepinephrine-dependent way. Biochemical and Biophysical Research Communications 466 247-253. (doi:10.1016/j.bbrc. 2015.09.018)

Warner A \& Mittag J 2014 Brown fat and vascular heat dissipation: The new cautionary tail. Adipocyte 3 221-223. (doi:10.4161/adip.28815)

Warner A, Rahman A, Solsjö P, Gottschling K, Davis B, Vennstrom B, Arner A \& Mittag J 2013 Inappropriate heat dissipation ignites brown fat thermogenesis in mice with a mutant thyroid hormone receptor $\alpha 1$. PNAS 110 16241-16246. (doi:10.1073/pnas.1310300110)

Wu J, Bostrom P, Sparks LM, Ye L, Choi JH, Giang AH, Khandekar M, Virtanen KA, Nuutila P, Schaart G et al. 2012 Beige adipocytes are a distinct type of thermogenic fat cell in mouse and human. Cell $\mathbf{1 5 0}$ 366-376. (doi:10.1016/j.cell.2012.05.016)

Wu MV, Bikopoulos G, Hung S \& Ceddia RB 2014 Thermogenic capacity is antagonistically regulated in classical brown and white subcutaneous fat depots by high fat diet and endurance training in rats: impact on whole-body energy expenditure. Journal of Biological Chemistry 289 34129-34140. (doi:10.1074/jbc.M114.591008)

Xiao C, Goldgof M, Gavrilova O \& Reitman ML 2015 Anti-obesity and metabolic efficacy of the $\beta 3$-adrenergic agonist, CL316243, in mice at thermoneutrality compared to 22 degrees C. Obesity 23 1450-1459. (doi:10.1002/oby.21124)

Xue B, Rim JS, Hogan JC, Coulter AA, Koza RA \& Kozak LP 2007 Genetic variability affects the development of brown adipocytes in white fat but not in interscapular brown fat. Journal of Lipid Research 48 41-51. (doi:10.1194/jlr.M600287-JLR200)

Xue R, Lynes MD, Dreyfuss JM, Shamsi F, Schulz TJ, Zhang H, Huang TL, Townsend KL, Li Y, Takahashi H et al. 2015 Clonal analyses and gene profiling identify genetic biomarkers of the thermogenic potential of human brown and white preadipocytes. Nature Medicine 21 760-768. (doi:10.1038/nm.3881)

Yoneshiro T, Aita S, Matsushita M, Kameya T, Nakada K, Kawai Y \& Saito M 2011 Brown adipose tissue, whole-body energy expenditure, and thermogenesis in healthy adult men. Obesity 19 13-16. (doi:10.1038/ oby.2010.105)

Received in final form 2 October 2015

Accepted 8 October 2015

Accepted Preprint published online 8 October 2015
(C) 2016 Society for Endocrinology Printed in Great Britain
Published by Bioscientifica Ltd. 